\title{
A phase 2 randomized, double-blind study of AMG 108, a fully human monoclonal antibody to IL-1R, in patients with rheumatoid arthritis
}

\author{
Mario H Cardiel ${ }^{1 *}$, Paul P Tak², William Bensen ${ }^{3}$, Francis X Burch ${ }^{4}$, Sarka Forejtova ${ }^{5}$, Janusz E Badurski ${ }^{6}$, \\ Tarundeep Kakkar ${ }^{7}$, Terry Bevirt ${ }^{8}$, Liyun Ni ${ }^{9}$, Ellen McCroskery ${ }^{10}$, Angelika Jahreis ${ }^{10}$, Debra J Zack ${ }^{10}$
}

\begin{abstract}
Introduction: Preclinical work has suggested that IL-1 plays a critical role in the pathogenesis of rheumatoid arthritis (RA). The objective of the present study was to determine the effect of a long-acting IL-1 receptor inhibitor, AMG 108, in a double-blind, placebo-controlled, parallel-dosing study in patients with active RA who were receiving stable methotrexate (15 to $25 \mathrm{mg} /$ week).
\end{abstract}

Methods: Patients were randomized equally to receive placebo or 50, 125, or 250 mg AMG 108 subcutaneously every 4 weeks for 6 months. The primary efficacy endpoint was a 20\% improvement in the American College of Rheumatology response (ACR20) at week 24; other efficacy endpoints included the ACR50, the ACR70, and the RA disease activity score (28-joint count Disease Activity Score) responses, patient-reported outcomes, and pharmacokinetic parameters. Safety endpoints included treatment-emergent adverse events (AEs), infectious AEs, serious AEs, serious infections, injection site reactions, laboratory abnormalities, and antibodies to AMG 108.

Results: Of 813 patients enrolled in the study, 204 patients were randomized to the $50 \mathrm{mg}$ group, 203 to the 125 $\mathrm{mg}$ group, 203 to the $250 \mathrm{mg}$ group, and 203 to placebo. At week 24, 40.4\% of the $250 \mathrm{mg}$ group, 36\% of the 125 $\mathrm{mg}$ group, $30.9 \%$ of the $50 \mathrm{mg}$ group, and $29.1 \%$ of the placebo group achieved an ACR20 ( $P=0.022,250 \mathrm{mg}$ vs. placebo). Of the individual ACR components, numerical dose-dependent improvements were only seen in tender joint counts, pain (visual analog scale), and the acute phase reactants, erythrocyte sedimentation rate and C-reactive protein. No dose-related increase was observed in the incidence of treatment-emergent AEs. No deaths were reported, and the incidence of AEs and infections, serious AEs and infections, and withdrawals from study for safety were similar in the AMG 108 and placebo groups.

Conclusions: This large double-blind randomized trial with a long-acting IL-1 receptor blocker, AMG 108, is consistent with the experience of other IL-1 blockers, represents a definitive experiment showing that IL-1 inhibition provides only moderate symptomatic amelioration of arthritis activity in the majority of RA patients, and provides an answer to a question that has been discussed for many years in the rheumatologic community.

Trial Registration: ClinicalTrials.gov NCT00293826.

\section{Introduction}

Rheumatoid arthritis (RA) is a chronic, systemic, autoimmune, inflammatory arthropathy of unknown etiology, characterized by progressive destruction of the affected joints, deformity, disability, and premature death [1].

\footnotetext{
* Correspondence: mhcardiel@hotmail.com

${ }^{1}$ Centro de Investigacion Clinica de Morelia, Morelia, Virrey de Mendoza

1998-Int. 522 Col Félix Ireta, Mich 58070, Mexico

Full list of author information is available at the end of the article
}

Genetic and environmental factors have been implicated in the pathogenesis of RA [2]. The inflammatory response in the synovial membrane includes hyperplasia, increased vascularity, and infiltration of inflammatory cells [3]. Various inflammatory cascades ultimately lead to activation of macrophages and fibroblast-like synoviocytes to overproduce proinflammatory cytokines such as IL-1, IL-6, and TNF $\alpha[4,5]$. Other cytokines, as well as

(C) 2010 Cardiel et al.; licensee BioMed Central Ltd. This is an open access article distributed under the terms of the Creative Commons 
matrix metalloproteinases, are produced that are responsible for cartilage degradation and bone erosion.

IL-1 is considered a pivotal cytokine in chronic destructive arthritis; it is a strong activator of chondrocytes, induces cartilage breakdown through upregulation of metalloproteinases, and causes profound suppression of cartilage matrix synthesis. IL-1 is also able to increase receptor activator of NF- $\kappa \mathrm{B}$ ligand expression and thus drive osteoclast formation and activation [6,7], leading to bony erosions. Several murine models have shown the arthritogenic and erosive potency of IL-1. In collageninduced arthritis, a frequently used animal model for RA, TNF was an important contributor to inflammation at the onset of disease, but IL-1 receptor (IL-1R) blockage was highly efficacious in reducing inflammation, both in acute and advanced stages [8]. In antigen-induced arthritis, cartilage damage, erosion progression, and propagation of inflammation are dependent on IL-1 $[9,10]$. In a recent study of immune complex arthritis, IL-1deficient mice were strongly protected [11]. In a novel transgenic mouse model of adjuvant arthritis, a pure $\mathrm{T}$-cell model, mice deficient in the IL-1R antagonist displayed uncontrolled IL-1 activity and developed spontaneous T-cell-dependent autoimmune arthritis [12]. Overall, the preclinical data strongly support a role for IL-1 in the pathogenesis of synovial inflammation.

In RA patients, however, IL-1 antagonists display relatively modest effects, although they are very effective in the treatment of systemic-onset juvenile idiopathic arthritis, of adult-onset Still's disease, and of several autoinflammatory disorders [13]. The question remains whether these inhibitors were given at doses and intervals that would be able to achieve robust coverage of the IL-1 pathway. We therefore investigated whether use of more continuous blockade of IL-1 could translate into increased efficacy in the treatment of RA.

AMG 108 (Amgen Inc., Thousand Oaks, CA, USA) is a fully human $\operatorname{IgG}_{2}$ monoclonal antibody that binds IL-1R type 1 and nonselectively inhibits the activity of both forms of IL-1 (IL-1 $\alpha$ and IL-1 $\beta$ ). The objective of the present study was to compare the efficacy and safety of three dose levels of AMG 108 with placebo in patients with active RA who were receiving stable methotrexate (MTX) (15 to $25 \mathrm{mg} /$ week).

\section{Materials and methods Patients}

Patients were enrolled at 132 study sites in North America (43\% of patients; United States, Canada, Mexico), Eastern Europe (43\% of patients; Poland, Czech Republic, Hungary, Slovakia, Estonia, Latvia), Western Europe (12\% of patients; Netherlands, Spain, Italy, United Kingdom, France, Belgium, Ireland, Sweden), and Australia (2\% of patients).
Eligible patients were $\geq 18$ and $\leq 70$ years old and had RA that met the American College of Rheumatology (ACR) classification criteria [14], with active RA for a duration $\geq 6$ months. Active RA was defined as $\geq 6$ swollen joints and $\geq 6$ tender or painful joints and at least one of the following: erythrocyte sedimentation rate (ESR) $\geq 28 \mathrm{~mm} /$ hour, C-reactive protein (CRP) $>2.0 \mathrm{mg} / \mathrm{dl}$, or duration of morning stiffness $\geq 45$ minutes at time of screening. Patients must have received MTX for at least 12 consecutive weeks, with a stable dose of oral or subcutaneous MTX at 15 to $25 \mathrm{mg} /$ week for $\geq 4$ weeks at time of screening. Exceptions were granted for a lower dose if it was the highest tolerated dose (toxicity documentation was required). Patients were allowed to be taking stable doses of nonsteroidal anti-inflammatory drugs or oral corticosteroids ( $\leq 10 \mathrm{mg}$ prednisone or equivalent) if doses were stable $\geq 4$ weeks before screening.

Patients were excluded from the study if they had received any previous AMG 108 or other commercial or experimental biologic therapies for RA or other inflammatory disease, or had uncontrolled or clinically significant systemic disease other than RA (for example, diabetes mellitus, cardiovascular disease, or hypertension). Patients could not have class IV RA as defined by ACR revised criteria for global functional status in RA [15], Felty's syndrome, a prosthetic joint infection within 5 years or native joint infection within 1 year of screening, or a major chronic inflammatory disease or connective tissue disease other than RA (with the exception of secondary Sjögren's syndrome). Patients could not have: uncontrolled or clinically significant asthma; known sensitivity to mammalian cell-derived drug products; malignancy within 5 years of screening (except for squamous or basal cell carcinoma or successfully treated in situ cervical cancer); serious infection (defined as requiring hospitalization) or recurrent, acute, or chronic infections within 8 weeks of screening; history of Mycobacterium tuberculosis or exposure; or known positivity for hepatitis $B$ surface antigen, hepatitis $C$ virus, or human immunodeficiency virus.

Patients were ineligible if they had any of the following clinically significant laboratory values at screening: white blood cell count $<3.0 \times 10^{9} / \mathrm{l}$, absolute neutrophil count $<2.5 \times 10^{9} /$ l, platelet count $<125 \times 10^{9} / \mathrm{l}$, aspartate aminotransferase or alanine aminotransferase $>1.5 \times$ upper limit of normal, serum creatinine $>1.5 \times$ upper limit of normal, or any other laboratory abnormality that, in the opinion of the investigator, would prevent the patient from completing the study or would interfere with the interpretation of the study results. Patients could not have received intraarticular or systemic corticosteroid injections or any investigational therapy within 4 weeks of screening, any disease-modifying antirheumatic drug other than MTX within 6 weeks of screening, cyclophosphamide within 
6 months of screening, or any live vaccine within 3 months of the first dose of investigational product. Patients were ineligible if, in the investigator's opinion, they had any physical or psychiatric disorder that could interfere with their ability to give informed consent or participate in the study. Patients with active substance abuse (within 6 months of screening) or any condition that might require narcotic analgesics were excluded. Pregnant or nursing women were not eligible, and all sexually active patients were required to use adequate contraception.

\section{Study design}

The investigation was a double-blind, placebo-controlled, parallel-dosing study in patients with active RA who were receiving stable doses of MTX (15 to $25 \mathrm{mg}$ /week), were biologic-naïve, and had discontinued disease-modifying antirheumatic drugs other than MTX prior to study entry. Patients were randomized equally to receive placebo or 50,125, or $250 \mathrm{mg}$ AMG 108 subcutaneously every 4 weeks for 6 months.

The study was conducted according to the Declaration of Helsinki and the International Conference on Harmonisation Tripartite Guideline on Good Clinical Practice [16]. Approvals from appropriate research ethics committees were obtained from each participating study center (Additional file 1). All patients provided written informed consent before participating. An external Data Monitoring Committee monitored patient safety throughout the duration of the study.

\section{Endpoints}

The primary efficacy endpoint was the ACR20 response [17] at week 24. Secondary efficacy endpoints included ACR50 and ACR70 responses and the individual components of the ACR; the Disease Activity Score using the 28-joint count (DAS28) (using CRP primarily; ESR was used only if CRP was missing) [18]; and patient-reported outcomes, including the Disability Index of the Health Assessment Questionnaire [19], and the physical and mental composite scores of the Short Form-36 [20] at week 24 . All of these endpoints over time in the study were analyzed as exploratory endpoints.

Safety endpoints included treatment-emergent adverse events (AEs), infectious AEs, serious AEs, serious infections, injection site reactions, laboratory abnormalities, and anti-AMG 108 antibodies.

The pharmacokinetic profile of AMG 108 in combination with MTX was also assessed (in 520 patients with sparse sampling, and in 37 patients with intensive sampling). A validated ELISA was used to quantify AMG 108 in the serum; IL-1R was used as the capture receptor, and biotinylated IL-1R was used for detection.

Binding antibodies to AMG 108 (anti-drug antibodies) were evaluated using a validated acid dissociation electrochemiluminescence-based bridging immunoassay. Serum samples were collected predose and at weeks 12, 24 , and 34 . A cell-based bioassay was used to detect neutralizing antibodies in samples that were positive in the immunoassay.

\section{Sample size}

The primary endpoint was the ACR20 response at week 24. The sample size of 196 patients per treatment arm was calculated to provide at least $80 \%$ power at a statistical significance level of 5\% (two-sided) to test whether monthly subcutaneous dosing of AMG 108 in combination with MTX demonstrated an ACR20 response at week 24 that was $>20 \%$ above that with MTX therapy alone in RA subjects. The sample size was inflated to allow for a $10 \%$ dropout rate over the course of the study.

\section{Statistical analysis}

Patients were analyzed according to the randomized treatment arm regardless of actual treatment received during the study. All efficacy endpoints were analyzed using the intent-to-treat analysis set, which included all randomized patients regardless of whether they received investigational product. The safety dataset included all patients who received $\geq 1$ dose of investigational product.

The primary efficacy endpoint compared the ACR20 response rate at week 24 in the $250 \mathrm{mg}$ AMG 108 group with that of the placebo group. All secondary endpoints were tested sequentially in a prespecified order to control the overall family-wise type 1 error rate at $5 \%$ (two-sided). The comparisons of proportions (for dichotomous variables) among treatment arms were carried out using Fisher's exact test. The comparisons of distribution-location parameters (for continuous and ordinal variables) among treatment arms were performed using the Wilcoxon rank-sum text. For dichotomous variables, missing values were imputed using a nonresponder imputation method; for continuous variables, the primary analysis is based on observed cases.

\section{Results}

\section{Patient disposition and disease characteristics}

The patient disposition is presented in Figure 1. Randomization was well balanced across groups: 204 patients were randomized to $50 \mathrm{mg}$ AMG 108, 203 patients to $125 \mathrm{mg}$ AMG 108, 203 patients to $250 \mathrm{mg}$ AMG 108, and 203 patients to placebo. Of 813 patients enrolled in the study, 805 (99\%) received $\geq 1$ dose of investigational product. Study completion at week 24 was similar across treatment groups: 88 to $90 \%$ in the AMG 108 groups vs. $93 \%$ in the placebo group.

Demographics and baseline disease characteristics are presented in Table 1 . Most patients were women $(\geq 76 \%$ in each group), and most were white ( $\geq 83 \%$ in each 


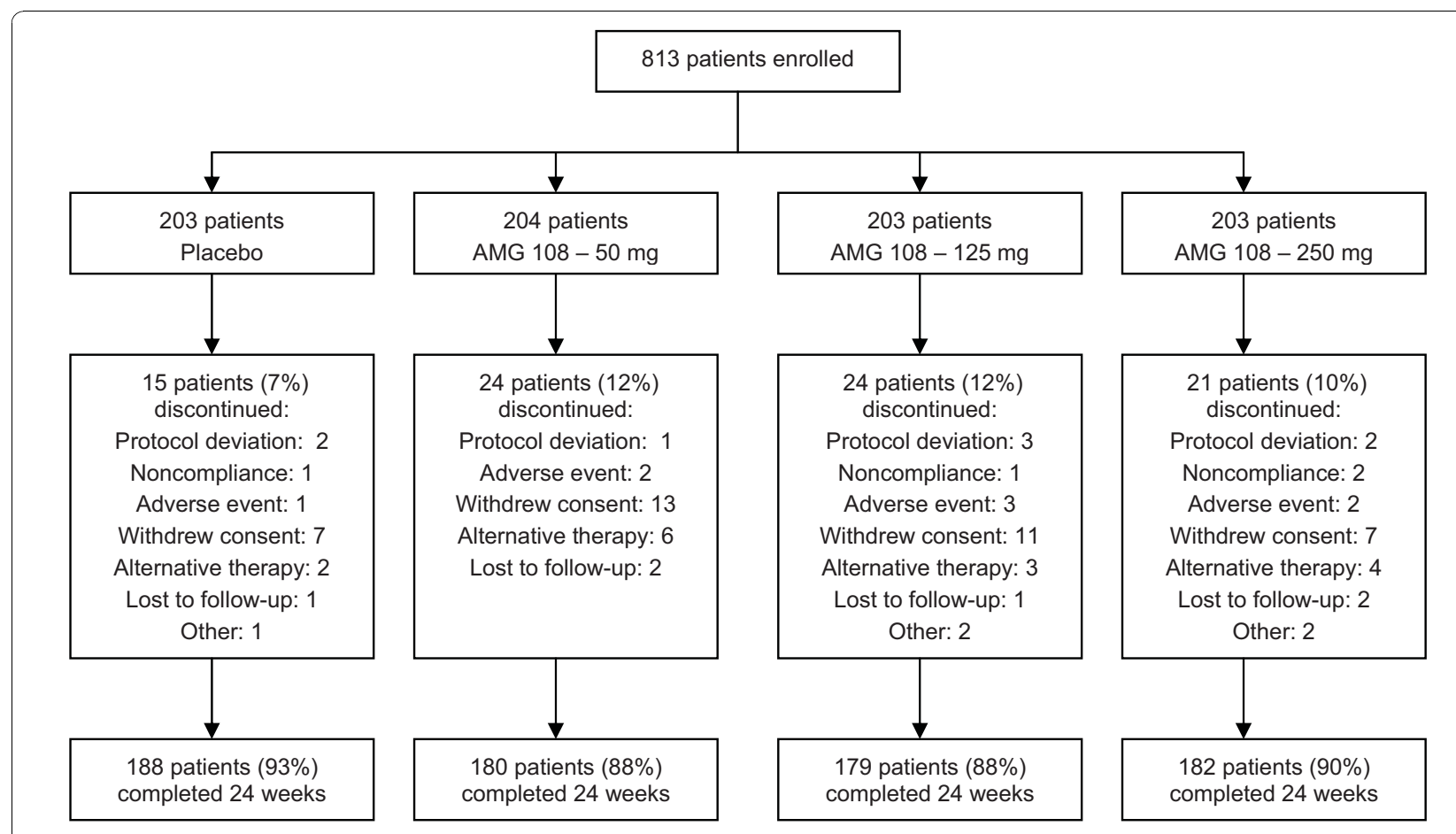

Figure 1 Patient disposition. CONSORT diagram.

group). The mean age was 51.8 years in the AMG 108 groups and was 52.1 years in the placebo group.

\section{Efficacy}

In the primary efficacy analysis at week 24 (using the nonresponder imputation method), the ACR20 response rate was statistically significantly higher in the $250 \mathrm{mg}$ AMG 108 group (40.4\%) compared with the placebo group $(29.1 \% ; P=0.022)$. Small improvements in the ACR20 response at week 24 were also seen in the 125 mg AMG 108 group (36.0\%; Table 2). The ACR20, ACR50, and ACR70 responses are presented in Table 2. Only the 250 mg AMG 108 group showed a significant improvement in ACR50 scores, and no groups were different from placebo with respect to ACR 70 .

Additionally, numerical dose-dependent responses were observed at week 24 in several individual components of the ACR, including tender joint count, pain (visual analog scale), ESR, and CRP; all components of the ACR are presented in Table 3. Responses were weak or absent in swollen joint count and physician and patient global assessments. Median ESR values are shown over time in Figure 2.

Results of the DAS28 CRP at week 24 are presented in Table 2. The $125 \mathrm{mg}$ and $250 \mathrm{mg}$ AMG 108 groups had significantly greater mean improvements from baseline compared with placebo at week $24(-0.92$ and -1.18 , respectively, vs. $-0.60 ; P<0.001)$. Of note, most patients had moderate disease activity at study entry, as shown by their baseline DAS28 CRP scores (Table 1). The European League Against Rheumatism 28-joint count responses (EULAR28) are also presented in Table 2.

Clinically meaningful improvements were observed in some patient-reported outcome measures. Mean improvements from baseline at week 24 in the Health Assessment Questionnaire Disability Index were greater in the $250 \mathrm{mg}$ and 125 mg AMG 108 groups (-0.40 and -0.34, respectively; $P<0.001$, each group compared with placebo) than in the $50 \mathrm{mg}$ group $(-0.24)$ or the placebo group $(-0.19)$. Mean improvements from baseline at week 24 in the physical composite score of the Short Form-36 were numerically greater in all AMG 108 groups (range 4.6 to 7.2 ) than in the placebo group (3.3), and were significantly greater in the $250 \mathrm{mg}$ group (7.2) compared with placebo $(P<$ $0.001)$. Improvements in the mental composite score, however, were similar among the AMG 108 and placebo groups (data not shown).

\section{Pharmacokinetics}

Following single-dose and multiple-dose administration, AMG 108 is slowly absorbed - with the median time at which the maximum concentration occurs ranging from 3.8 to 3.9 days ( $50 \mathrm{mg}$ group), from 3.9 to 4.0 days (125 mg group), and from 5.9 to 7.0 days $(250 \mathrm{mg}$ 
Table 1 Baseline demographics and disease characteristics

\begin{tabular}{|c|c|c|c|c|c|}
\hline & \multirow[b]{2}{*}{$\begin{array}{l}\text { Placebo } \\
(n=203)\end{array}$} & \multicolumn{4}{|c|}{ AMG 108} \\
\hline & & $\begin{array}{l}50 \mathrm{mg} \\
(n=204)\end{array}$ & $\begin{array}{l}125 \mathrm{mg} \\
(n=203)\end{array}$ & $\begin{array}{l}250 \mathrm{mg} \\
(n=203)\end{array}$ & $\begin{array}{l}\text { Total } \\
(n=610)\end{array}$ \\
\hline Mean age (years) & 52.1 & 51.4 & 51.7 & 52.2 & 51.8 \\
\hline \multicolumn{6}{|l|}{ Age group, $n(\%)$} \\
\hline$<65$ years & $185(91.1)$ & $171(83.8)$ & $176(86.7)$ & $184(90.6)$ & $531(87.0)$ \\
\hline$\geq 65$ years & $18(8.9)$ & $33(16.2)$ & $27(13.3)$ & $19(9.4)$ & $79(13.0)$ \\
\hline Female, $n(\%)$ & $158(77.8)$ & $155(76.0)$ & $163(80.3)$ & $160(78.8)$ & $478(78.4)$ \\
\hline \multicolumn{6}{|l|}{ Ethnicity, $n(\%)$} \\
\hline White & $168(82.8)$ & $169(82.8)$ & $177(87.2)$ & $179(88.2)$ & $525(86.1)$ \\
\hline Hispanic & $27(13.3)$ & $24(11.8)$ & $18(8.9)$ & $17(8.4)$ & $59(9.7)$ \\
\hline Other $^{a}$ & $8(3.9)$ & $11(5.4)$ & $8(3.9)$ & $7(3.4)$ & $26(4.3)$ \\
\hline Mean weight (kg) & 76.4 & 77.2 & 74.2 & 75.0 & 75.4 \\
\hline Mean height $(\mathrm{cm})$ & 164.0 & 164.6 & 164.0 & 164.8 & 164.5 \\
\hline Mean body mass index $\left(\mathrm{kg} / \mathrm{m}^{2}\right)$ & 28.4 & 28.4 & 27.5 & 27.5 & 27.8 \\
\hline Mean duration of RA (years) & 7.6 & 7.3 & 7.5 & 8.0 & 7.6 \\
\hline \multicolumn{6}{|l|}{ Subcomponent of ACR (mean) } \\
\hline Tender joint count & 26.3 & 26.5 & 24.8 & 26.9 & 26.1 \\
\hline Swollen joint count & 16.8 & 16.8 & 15.8 & 15.7 & 16.1 \\
\hline Patient global assessment & 5.9 & 6.2 & 6.1 & 6.1 & 6.2 \\
\hline Physician global assessment & 6.2 & 6.3 & 6.3 & 6.5 & 6.4 \\
\hline Patient pain assessment & 51.2 & 53.9 & 53.5 & 57.0 & 54.8 \\
\hline HAQ Disability Index & 1.4 & 1.5 & 1.5 & 1.5 & 1.5 \\
\hline C-reactive protein (mg/dl) & 1.2 & 1.8 & 1.5 & 1.4 & 1.6 \\
\hline ESR (mm/hour) & 33.4 & 40.1 & 35.6 & 35.5 & 37.1 \\
\hline Mean DAS28 CRP & 4.7 & 4.9 & 4.7 & 4.8 & 4.8 \\
\hline Mean DAS28 ESR & 5.3 & 5.4 & 5.3 & 5.4 & 5.3 \\
\hline Mean tender joint count (28 joints) & 14.0 & 14.5 & 13.5 & 14.0 & 14.0 \\
\hline Mean swollen joint count (28 joints) & 11.3 & 10.6 & 10.8 & 11.2 & 11.0 \\
\hline
\end{tabular}

ACR, American College of Rheumatology; DAS28, Disease Activity Score (28-joint count); ESR, erythrocyte sedimentation rate; HAQ, Health Assessment Questionnaire; RA, rheumatoid arthritis. ${ }^{a}$ Black, Asian, American Indian or Alaska native, native Hawaiian or other Pacific Islander.

Table 2 ACR responses, DAS28 C-reactive protein, and EULAR28 responses at week 24

\begin{tabular}{|c|c|c|c|c|}
\hline & \multirow[b]{2}{*}{$\begin{array}{l}\text { Placebo } \\
(n=203)\end{array}$} & \multicolumn{3}{|c|}{ AMG 108} \\
\hline & & $\begin{array}{l}50 \mathrm{mg} \\
(n=204)\end{array}$ & $\begin{array}{l}125 \mathrm{mg} \\
(n=203)\end{array}$ & $\begin{array}{l}250 \mathrm{mg} \\
(n=203)\end{array}$ \\
\hline \multicolumn{5}{|l|}{ ACR response, $n(\%)^{\mathrm{a}}$} \\
\hline ACR20 & $59(29.1)$ & $63(30.9)(P=0.746)$ & $73(36.0)(P=0.168)$ & $82(40.4)(P=0.022)$ \\
\hline ACR50 & $17(8.4)$ & $24(11.8)(P=0.323)$ & $28(13.8)(P=0.113)$ & $41(20.2)(P<0.001)$ \\
\hline ACR70 & $8(3.9)$ & $4(2.0)(P=0.259)$ & $5(2.5)(P=0.575)$ & $12(5.9)(P=0.492)$ \\
\hline DAS28 CRP, mean change from baseline ${ }^{b}$ & -0.60 & $-0.69(P=0.213)$ & $-0.92(P<0.001)$ & $-1.18(P<0.001)$ \\
\hline \multicolumn{5}{|l|}{ EULAR2 8 response, $n(\%)^{c}$} \\
\hline Good & $16(8 \%)$ & $20(10 \%)$ & $28(13.9 \%)$ & $39(19.5 \%)$ \\
\hline Moderate & $61(30.7 \%)$ & $59(29.3 \%)$ & $76(37.8 \%)$ & $76(38 \%)$ \\
\hline No response & $122(61.3 \%)$ & $122(60.7 \%)$ & $97(48.3 \%)$ & $85(42.5 \%)$ \\
\hline
\end{tabular}

ACR, American College of Rheumatology; CRP, C-reactive protein; DAS28, Disease Activity Score (28-joint count); EULAR28, European League Against Rheumatism (28-joint count). ${ }^{a}$ Nonresponder imputation: missing ACR responses were imputed as nonresponder. $P$ values are nominal without multiplicity adjustment, using Fisher's exact test. ${ }^{b}$ Observed cases. $P$ values are comparisons with placebo, using two-sided Wilcoxon rank-sum test. 'EULAR28 response is classified as good, moderate, and no response based on the DAS28 ESR at week 24 and the DAS28 ESR improvement from baseline at week 24 [31]. 
Table 3 Improvements in American College of Rheumatology and DAS28 components at week 24

\begin{tabular}{|c|c|c|c|c|}
\hline & \multirow[b]{2}{*}{$\begin{array}{l}\text { Placebo } \\
(n=203)\end{array}$} & \multicolumn{3}{|c|}{ AMG 108} \\
\hline & & $\begin{array}{l}50 \mathrm{mg} \\
(n=204)\end{array}$ & $\begin{array}{l}125 \mathrm{mg} \\
(n=203)\end{array}$ & $\begin{array}{l}250 \mathrm{mg} \\
(n=203)\end{array}$ \\
\hline \multicolumn{5}{|l|}{ Tender joint count (68 joints) } \\
\hline Mean (SD) \% change & $-20.0(127.5)$ & $-29.5(60.4)$ & $-35.7(43.6)$ & $-40.2(44.3)$ \\
\hline Median \% change & -31.3 & -38.4 & -40.0 & -46.7 \\
\hline \multicolumn{5}{|l|}{ Swollen joint count (66 joints) } \\
\hline Mean (SD) \% change & $-32.2(50.0)$ & $-33.7(46.5)$ & $-33.8(114.8)$ & $-39.1(53.3)$ \\
\hline Median \% change & -33.1 & -40.8 & -46.3 & -47.1 \\
\hline \multicolumn{5}{|l|}{ Patient global assessment } \\
\hline Mean (SD) \% change & $-11.6(49.8)$ & $-16.7(43.8)$ & $-21.6(48.2)$ & $-17.8(64.5)$ \\
\hline Median \% change & -20.0 & -16.7 & -28.6 & -20.0 \\
\hline \multicolumn{5}{|l|}{ Physician global assessment } \\
\hline Mean (SD) \% change & $-30.1(33.7)$ & $-36.0(30.4)$ & $-36.2(33.2)$ & $-43.0(30.8)$ \\
\hline Median \% change & -33.3 & -37.5 & -40.0 & -50.0 \\
\hline \multicolumn{5}{|l|}{ Pain (visual analog scale) } \\
\hline Mean (SD) \% change & $2.2(142.6)$ & $-11.4(76.3)$ & $-20.6(60.6)$ & $-30.9(46.9)$ \\
\hline Median \% change & -12.8 & -20.0 & -28.9 & -34.7 \\
\hline \multicolumn{5}{|l|}{ HAQ Disability Index } \\
\hline Mean (SD) \% change & $-11.1(53.0)$ & $-12.2(40.6)$ & $-20.5(48.2)$ & $-25.2(44.6)$ \\
\hline Median \% change & -11.4 & -13.3 & -20.0 & -25.0 \\
\hline \multicolumn{5}{|c|}{ Erythrocyte sedimentation rate } \\
\hline Mean (SD) \% change & $12.7(77.7)$ & $5(124.3)$ & $-18.3(68.7)$ & $-30.4(73.7)$ \\
\hline Median \% change & -6.3 & -13.2 & -36.8 & -46.7 \\
\hline \multicolumn{5}{|l|}{ C-reactive protein } \\
\hline Mean (SD) \% change & $123.2(695.3)$ & $32.2(164.0)$ & $-1.9(181.5)$ & $-25.5(168.5)$ \\
\hline Median \% change & 5.1 & -12.4 & -41.2 & -59.4 \\
\hline \multicolumn{5}{|l|}{ Tender joint count (28 joints) } \\
\hline Mean (SD) \% change & $-13.2(143.7)$ & $-21.0(73.2)$ & $-31.6(58.7)$ & $-36.5(65.7)$ \\
\hline Median \% change & -33.3 & -33.3 & -40.0 & -44.4 \\
\hline \multicolumn{5}{|l|}{ Swollen joint count (28 joints) } \\
\hline Mean (SD) \% change & $-28.2(52.7)$ & $-30.0(48.1)$ & $-28.7(118.3)$ & $-38.0(52.2)$ \\
\hline Median \% change & -33.3 & -33.3 & -44.4 & -44.4 \\
\hline
\end{tabular}

DAS28, Disease Activity Score (28-joint count); HAQ, health assessment questionnaire; SD, standard deviation.

group). Trough pharmacokinetic levels in the $250 \mathrm{mg}$ dose group were approximately 10 -fold above the predicted $90 \%$ inhibitory concentration for IL-1 (Table 4). Importantly, trough pharmacokinetic levels were maintained in the $125 \mathrm{mg}$ and $250 \mathrm{mg}$ groups, suggesting prolonged coverage of the IL-1 pathway.

\section{Safety}

AMG 108 was well tolerated at all doses administered during the study. No increase in incidence of treatmentemergent AEs was observed with increasing AMG 108 dose (Table 5). No deaths were reported, and the incidence of AEs, infectious AEs, serious AEs and infections, and withdrawals from study due to AEs were no higher in AMG 108 groups than in the placebo group (Table 5).
Injection-site reactions occurred more frequently in AMG 108 groups than in the placebo group (Table 5), but most reactions were mild or moderate in severity, with the majority of cases lasting $<5$ days. Of the 604 patients who received $\geq 1$ dose of AMG 108, 83 patients (13.7\%) were positive for binding antibodies to AMG 108 at some time during the study; 22 patients (4\%) were positive for neutralizing antibodies (data not shown).

No clinically significant changes in laboratory abnormalities were observed, with the exception of expected decreases in the absolute neutrophil count and platelet counts that were dose related; these decreases recovered to baseline values by the end-of-study evaluation (week 34; 10 weeks following the last dose of AMG 108). The median decreases in neutrophil counts over time are shown by visit and by treatment group in Figure 3 . 


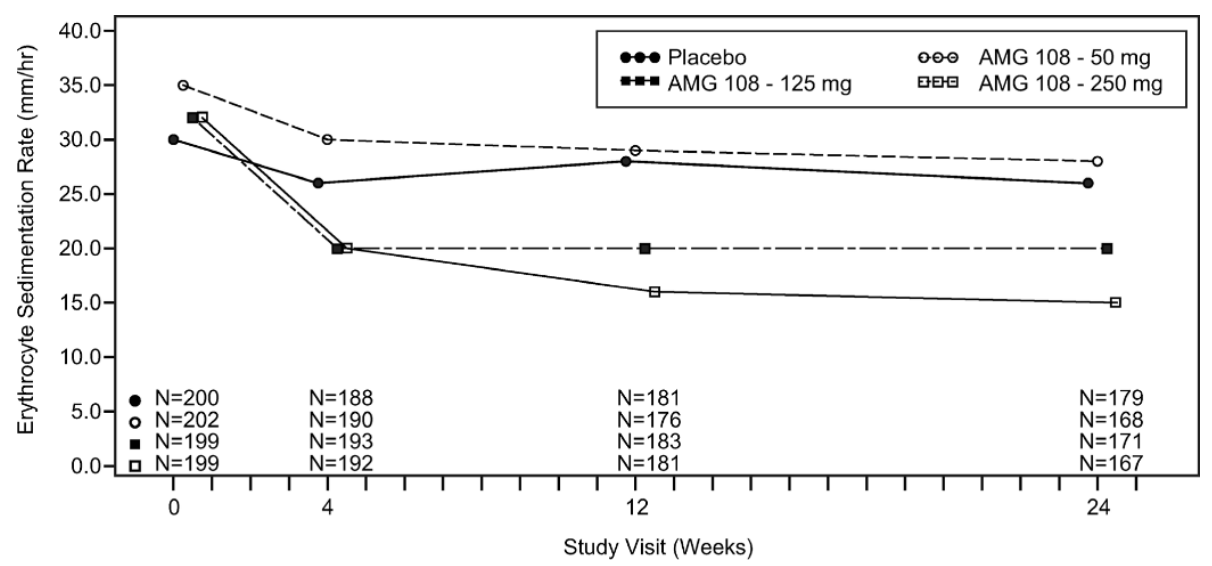

Figure 2 Median erythrocyte sedimentation rate over time.

\section{Discussion}

In the present study of AMG 108 - a long-acting IL-1R inhibitor - improvements in the signs and symptoms of RA as measured by the ACR20 were greater in the 250 mg AMG 108 group (40.4\%) at week 24, compared with the placebo group (29.1\%; $P=0.022)$. Improvements in the ACR50 were also statistically significant for the 250 mg AMG 108 group compared with placebo; however, the numbers of patients with ACR50 responses were low (20.2\% vs. 8.4\%, $250 \mathrm{mg}$ AMG 108 vs. placebo, respectively; $P<0.001)$. The ACR70 response was not significantly different between the two groups. Of note, mean responses on the Health Assessment Questionnaire Disability Index observed in all groups treated with AMG 108 were above the minimum clinically important difference $(0.22)$ published for this outcome measure [21]. It is interesting that the components of the ACR responses showing dose-dependent effects in this study were those that are consistent with the known functions of IL-1 in pain [22] and in the acute phase response [23]: AMG 108 decreased pain, tender joints, ESR, and CRP. The other components of the ACR scoring system were not affected. AMG 108 was well tolerated in this patient population, with a safety profile similar to that of placebo. No dose-related increases were observed in the incidence of AEs, and no unanticipated events were reported.
Of interest, the effectiveness of IL-1R blockade with a long-acting receptor blocker, AMG 108, appears to be moderate and similar to those described with other IL-1 blockers (such as anakinra, pralnacasan, and IL-1 TRAP) [24-26], despite a constant concentration of drug estimated to be 10 -fold higher than the predicted $90 \%$ inhibitory concentration for IL-1. The limited efficacy of IL-1 blockers in RA therefore appears not to be explained solely by pharmacokinetic or pathway coverage, since the efficacy provided by AMG 108 was similar to that in other IL-1 inhibitor studies [27] despite constant inhibition of the IL-1 pathway for a 6-month period with AMG 108.

The results of treatment with AMG 108 instead appear to point to a limited role of IL-1 in human RA synovial inflammation - a notion supported by the profound effect seen with other IL-1 inhibitors in conditions other than RA, such as systemic-onset juvenile idiopathic arthritis, gout, neonatal-onset multisystem inflammatory disease, cryopyrin-associated periodic syndromes, and other autoinflammatory disorders $[28,29]$. Although it is not known how many IL-1Rs have to be blocked to prevent IL-1 binding and signaling in a substantial way, AMG 108 achieved steady concentrations in the $250 \mathrm{mg} / \mathrm{month}$ dosing arm that should have been 10-fold higher than those needed to inhibit $90 \%$ of IL-1 signaling. In addition, dose-dependent changes were seen in those parameters known to be affected by IL-1, such as pain and acute

Table 4 Summary of AMG 108 trough concentration (nM) at 20 and 24 weeks

\begin{tabular}{|c|c|c|c|c|c|c|}
\hline & \multicolumn{2}{|c|}{50 mg AMG 108} & \multicolumn{2}{|c|}{125 mg AMG 108} & \multicolumn{2}{|c|}{250 mg AMG 108} \\
\hline & Week $20(n=144)$ & Week $24(n=137)$ & Week $20(n=146)$ & Week $24(n=140)$ & Week $20(n=137)$ & Week $24(n=138)$ \\
\hline Mean & 0 & 0 & 16.5 & 19.8 & 155 & 160 \\
\hline Median & 0 & 0 & 6.25 & 4.65 & 139 & 141 \\
\hline Range & 0 to 6.43 & 0 to 0.32 & 0 to 104 & 0 to 268 & 0 to 417 & 0 to 1,000 \\
\hline
\end{tabular}

Below quantifiable levels reported as $0.90 \%$ inhibitory concentration $=13.5 \mathrm{nM}, 50 \%$ inhibitory concentration $=1.5 \mathrm{nM}$. 
Table 5 Summary of adverse events through 24 weeks

\begin{tabular}{|c|c|c|c|c|c|}
\hline & \multirow[b]{2}{*}{$\begin{array}{l}\text { Placebo } \\
(n=201)\end{array}$} & \multicolumn{4}{|c|}{ AMG 108} \\
\hline & & $\begin{array}{l}50 \mathrm{mg} \\
(n=202)\end{array}$ & $\begin{array}{l}125 \mathrm{mg} \\
(n=201)\end{array}$ & $\begin{array}{l}250 \mathrm{mg} \\
(n=201)\end{array}$ & $\begin{array}{l}\text { Total }^{\mathrm{a}} \\
(n=604)\end{array}$ \\
\hline Any $A E$ & $133(66.2)$ & $134(66.3)$ & $143(71.1)$ & $135(67.2)$ & $412(68.2)$ \\
\hline \multicolumn{6}{|l|}{ Most common AE } \\
\hline Headache & $16(8.0)$ & $11(5.4)$ & $15(7.5)$ & $15(7.5)$ & $41(6.8)$ \\
\hline Diarrhea & $13(6.5)$ & $10(5.0)$ & $11(5.5)$ & $15(7.5)$ & $36(6.0)$ \\
\hline Nasopharyngitis & $18(9.0)$ & $11(5.4)$ & $13(6.5)$ & $12(6.0)$ & $36(6.0)$ \\
\hline URI & $15(7.5)$ & $10(5.0)$ & $13(6.5)$ & $13(6.5)$ & $36(6.0)$ \\
\hline Treatment-related AE & $48(23.9)$ & $43(21.3)$ & $50(24.9)$ & $45(22.4)$ & $138(22.8)$ \\
\hline \multicolumn{6}{|l|}{ AE leading to: } \\
\hline Study discontinuation & $1(0.5)$ & $3(1.5)$ & $3(1.5)$ & $3(1.5)$ & $9(1.5)$ \\
\hline Withdrawal of study drug & $2(1.0)$ & $4(2.0)$ & $4(2.0)$ & $3(1.5)$ & $11(1.8)$ \\
\hline Hospitalization & $9(4.5)$ & $5(2.5)$ & $5(2.5)$ & $6(3.0)$ & $16(2.6)$ \\
\hline Any infection & $72(35.8)$ & $64(31.7)$ & $68(33.8)$ & $62(30.8)$ & $194(32.1)$ \\
\hline \multicolumn{6}{|l|}{ Infection leading to: } \\
\hline Study discontinuation & $1(0.5)$ & 0 & 0 & $1(0.5)$ & $1(0.2)$ \\
\hline Withdrawal of study drug & 0 & $1(0.5)$ & 0 & $1(0.5)$ & $2(0.3)$ \\
\hline Hospitalization & $3(1.5)$ & $1(0.5)$ & $1(0.5)$ & $2(1.0)$ & $4(0.7)$ \\
\hline Injection site reaction & $5(2.5)$ & $8(4.0)$ & $10(5.0)$ & $9(4.5)$ & $27(4.5)$ \\
\hline Any serious $A E$ & $11(5.5)$ & $6(3.0)$ & $6(3.0)$ & $9(4.5)$ & $21(3.5)$ \\
\hline Treatment-related serious AE & $2(1.0)$ & $2(1.0)$ & $1(0.5)$ & $1(0.5)$ & $4(0.7)$ \\
\hline Serious infection & $3(1.5)$ & $2(1.0)$ & $1(0.5)$ & $2(1.0)$ & $5(0.8)$ \\
\hline Death & 0 & 0 & 0 & 0 & 0 \\
\hline
\end{tabular}

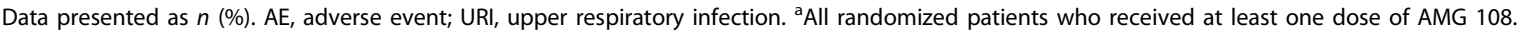

phase reactants. This discrepancy of the IL-1 effect between the animal models and RA patients may therefore be due to differences in timing of treatment, with animals treated at very early stages of disease and RA patients at later stages of chronic synovial inflammation, or may instead be due to differences between the cytokine interactions in rodents versus humans [30].

A limitation of the present study is the absence of radiographic evaluation. The primary analysis was focused on clinical signs and symptoms rather than on joint damage measured radiographically; we therefore do not know whether a more robust benefit than shown in the clinical findings would have been achieved if radiographs had been evaluated. Our results may possibly reflect a partial uncoupling of clinical and radiographic findings.

\section{Conclusions}

The present large, double-blind, randomized trial with a long-acting IL-1R blocker, AMG 108, is consistent with the experience of other IL-1 blockers, represents a

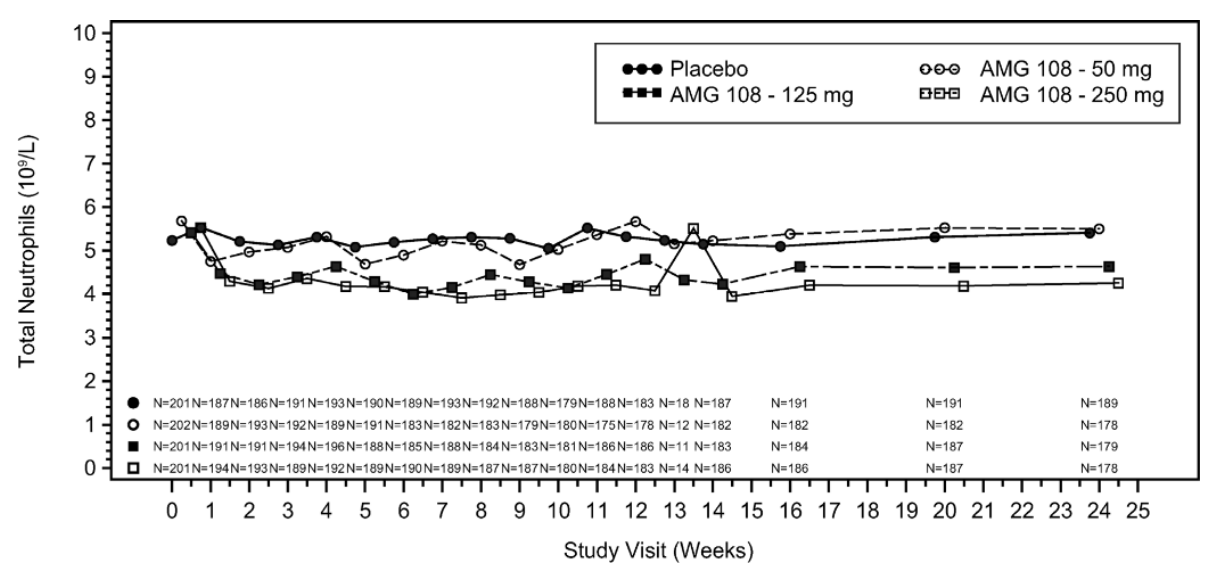

Figure 3 Median neutrophil counts over time by visit and by treatment group. 
definitive experiment showing that IL-1 inhibition provides only moderate symptomatic amelioration of arthritis activity in the majority of RA patients, and provides an answer to a question that has been discussed for many years in the rheumatologic community - whether use of more continuous blockade of IL-1 could translate into increased efficacy in the treatment of RA.

\section{Additional material}

Additional file 1: Investigator site list. Table listing the principal investigators and full study center details.

\section{Abbreviations}

ACR: American College of Rheumatology; AE: adverse event; CRP: C-reactive protein; DAS28: Disease Activity Score (28-joint count); ELISA: enzyme-linked immunosorbent assay; ESR: erythrocyte sedimentation rate; IL: interleukin; IL-1R: interleukin-1 receptor; MTX: methotrexate; NF: nuclear factor; RA: rheumatoid arthritis; TNF: tumor necrosis factor.

\section{Acknowledgements}

The authors wish to thank all the investigators and their staff at each institution for their participation in this multicenter trial. Writing assistance was provided by Linda Melvin, whose work was funded by Amgen Inc. Editorial assistance was provided by Michele Vivirito, who is employed by Amgen Inc. Amgen Inc. provided funding for the research and assisted with the study design; collection, analysis, and interpretation of data; writing the manuscript; and making the decision to submit the manuscript for publication.

\section{Author details}

${ }^{1}$ Centro de Investigacion Clinica de Morelia, Morelia, Virrey de Mendoza 1998-Int. 522 Col Félix Ireta, Mich 58070, Mexico. ${ }^{2}$ Department of Clinical Immunology/Rheumatology, Academic Medical Center/University of Amsterdam, Meibergdreef 9, Amsterdam 1105 AZ, The Netherlands. ${ }^{3}$ St Joseph's Hospital, McMaster University, 25 Charlton Avenue East, Hamilton, ON, L8N 1Y2, Canada. ${ }^{4}$ San Antonio Center for Clinical Research, 8527 Village Drive, San Antonio, TX 78217, USA. ${ }^{5}$ Revmatologicky ustav, Na Slupi 4, Praha 128 50, Czech Republic. ${ }^{6}$ Centrum Osteoporozy i Chorób Kostno-Stawowych, Waryńskiego 6/2, 15-461 Białystok, Poland. ${ }^{7}$ Pharmacokinetics and Drug Metabolism, Amgen Inc., One Amgen Center Drive, Thousand Oaks, CA 91320, USA. ${ }^{8} \mathrm{Global}$ Development Operations, Amgen Inc., One Amgen Center Drive, Thousand Oaks, CA 91320, USA. ${ }^{9}$ Global Biostats and Epidemiology, Amgen Inc., One Amgen Center Drive, Thousand Oaks, CA 91320, USA. ${ }^{10}$ Global Development, General Medicine and Inflammation Therapeutic Area, Amgen Inc., One Amgen Center Drive, Thousand Oaks, CA, 91320, USA.

\section{Authors' contributions}

TK, TB, LN, EM, AJ and DJZ made substantial contributions to the study concept or design. MHC, PPT, WB, FXB, SF and JEB assisted with the acquisition of the data. TK and LN performed data analysis. All authors assisted with interpretation of the data, helped to draft and revise the manuscript for intellectual content. All authors read and approved the final manuscript.

\section{Competing interests}

MHC, PPT, WB, FXB, SF and JEB received research funding from Amgen Inc; in addition, $\mathrm{MHC}$, PPT and WB have received consultant or speaker fees from Amgen Inc. TK, TB, LN, EM, AJ and DJZ are current or former full-time employees of, and hold stock in, Amgen Inc. Amgen Inc. is a patent-holder on AMG 108.

Received: 8 April 2010 Revised: 10 September 2010 Accepted: 15 October 2010 Published: 15 October 2010
References

1. Wolfe F, Mitchell DM, Sibley JT, Fries JF, Bloch DA, Williams CA, Spitz PW, Haga M, Kleinheksel SM, Cathey MA: The mortality of rheumatoid arthritis. Arthritis Rheum 1994, 37:481-494.

2. Plenge RM, Padyukov L, Remmers EF, Purcell $S$, Lee AT, Karlson EW, Wolfe F, Kastner DL, Alfredsson L, Altshuler D, Gregersen PK, Klareskog L, Rioux JD: Replication of putative candidate-gene associations with rheumatoid arthritis in $>4,000$ samples from North America and Sweden: association of susceptibility with PTPN22, CTLA4, and PADI4. Am J Hum Genet 2005, 77:1044-1060.

3. Tak PP, Smeets TJ, Daha MR, Kluin PM, Meijers KA, Brand R, Meinders AE, Breedveld FC: Analysis of the synovial cell infiltrate in early rheumatoid synovial tissue in relation to local disease activity. Arthritis Rheum 1997, 40:217-225.

4. Tak PP, Bresnihan B: The pathogenesis and prevention of joint damage in rheumatoid arthritis: advances from synovial biopsy and tissue analysis. Arthritis Rheum 2000, 43:2619-2633.

5. Firestein GS: Evolving concepts of rheumatoid arthritis. Nature 2003, 423:356-361

6. Lee SK, Gardner AE, Kalinowski JF, Jastrzebski SL, Lorenzo JA: RANKLstimulated osteoclast-like cell formation in vitro is partially dependent on endogenous interleukin-1 production. Bone 2006, 38:678-685.

7. Kim JH, Jin HM, Kim K, Song I, Youn BU, Matsuo K, Kim N: The mechanism of osteoclast differentiation induced by IL-1. J Immunol 2009, 183:1862-1870.

8. Joosten LA, Helsen MM, van de Loo FA, van den Berg WB: Anticytokine treatment of established type II collagen-induced arthritis in DBA/1 mice. A comparative study using anti-TNF alpha, anti-IL-1 alpha/beta, and IL-1Ra. Arthritis Rheum 1996, 39:797-809.

9. van de Loo FA, Joosten $L A$, van Lent PL, Arntz OJ, van den Berg WB: Role of interleukin-1, tumor necrosis factor alpha, and interleukin-6 in cartilage proteoglycan metabolism and destruction. Effect of in situ blocking in murine antigen- and zymosan-induced arthritis. Arthritis Rheum 1995, 38:164-172.

10. van Meurs JB, van Lent PL, Bayne EK, van de Loo FA, van den Berg WB: Interleukin-1 receptor antagonist prevents expression of the metalloproteinase-generated neoepitope VDIPEN in antigen-induced arthritis. Arthritis Rheum 1998, 41:647-656.

11. Monach PA, Benoist C, Mathis D: The role of antibodies in mouse models of rheumatoid arthritis, and relevance to human disease. Adv Immunol 2004, 82:217-248.

12. Horai R, Saijo S, Tanioka H, Nakae S, Sudo K, Okahara A, Ikuse T, Asano M, Iwakura $Y$ : Development of chronic inflammatory arthropathy resembling rheumatoid arthritis in interleukin 1 receptor antagonist-deficient mice. $J$ Exp Med 2000, 191:313-320.

13. Burger D, Dayer JM, Palmer G, Gabay C: Is IL-1 a good therapeutic target in the treatment of arthritis? Best Pract Res Clin Rheumatol 2006, 20:879-896.

14. Arnett FC, Edworthy SM, Bloch DA, MCShane DJ, Fries JF, Cooper NS, Healey LA, Kaplan SR, Liang MH, Luthra HS, Medsger TA Jr, Mitchell DM, Neustadt DH, Pinals RS, Schaller JG, Sharp JT, Wilder RL, Hunder GG: The American Rheumatism Association 1987 revised criteria for the classification of rheumatoid arthritis. Arthritis Rheum 1988, 31:315-324.

15. Hochberg MC, Chang RW, Dwosh I, Lindsey S, Pincus T, Wolfe F: The American College of Rheumatology 1991 revised criteria for the classification of global functional status in rheumatoid arthritis. Arthritis Rheum 1992, 35:498-502.

16. ICH Good Clinical Practices. [http://www.ich.org/LOB/media/MEDIA482. pdf].

17. Felson DT, Anderson JJ, Boers M, Bombardier C, Furst D, Goldsmith C, Katz LM, Lightfoot RJr, Paulus H, Strand V, Tugwell P, Weinblatt M, Williams HJ, Wolfe F, Kieszak S: American College of Rheumatology. Preliminary definition of improvement in rheumatoid arthritis. Arthritis Rheum 1995, 38:727-735.

18. Prevoo $M L$, van 't Hof $M A$, Kuper $H H$, van Leeuwen $M A$, van de Putte $L B$, van Riel PL: Modified disease activity scores that include twenty-eightjoint counts. Development and validation in a prospective longitudinal study of patients with rheumatoid arthritis. Arthritis Rheum 1995, 38:44-48.

19. Bruce B, Fries JF: The Health Assessment Questionnaire (HAQ). Clin Exp Rheumatol 2005, 23:S14-S18. 
20. Brazier JE, Harper R, Jones NM, O'Cathain A, Thomas KJ, Usherwood T, Westlake L: Validating the SF-36 health survey questionnaire: new outcome measure for primary care. BMJ 1992, 305:160-164.

21. Wells GA, Tugwell P, Kraag GR, Baker PR, Groh J, Redelmeier DA: Minimum important difference between patients with rheumatoid arthritis: the patient's perspective. J Rheumatol 1993, 20:557-560.

22. Ren $\mathrm{K}$, Torres $\mathrm{R}$ : Role of interleukin-1 $\beta$ during pain and inflammation. Brain Res Rev 2009, 60:57-64.

23. Eklund CM: Proinflammatory cytokines in CRP baseline regulation. Adv Clin Chem 2009, 48:111-136.

24. Molto A, Olive A: Anti-IL-1 molecules: new comers and new indications. Joint Bone Spine 2010, 77:102-107.

25. Rudolphi K, Gerwin N, Verzijl N, van der Kraan P, van den Berg W: Pralnacasan, an inhibitor of interleukin-1 $\beta$ converting enzyme, reduces joint damage in two murine models of osteoarthritis. Osteoarthritis Cartilage 2003, 11:738-746.

26. Gabay C: IL-1 trap. Regeneron/Novartis. Curr Opin Investig Drugs 2003, 4:593-597.

27. Mertens M, Singh JA: Anakinra for rheumatoid arthritis: a systematic review. J Rheumatol 2009, 36:1118-1125.

28. Kalliolias $\mathrm{GD}$, Liossis $\mathrm{SN}$ : The future of the IL-1 receptor antagonist anakinra: from rheumatoid arthritis to adult-onset Still's disease and systemic-onset juvenile idiopathic arthritis. Expert Opin Investig Drugs 2008, 17:349-359.

29. Stahl N, Radin A, Mellis S: Rilonacept - CAPS and beyond. Ann N Y Acad Sci 2009, 1182:124-134

30. Bevaart L, Vervoordeldonk MJ, Tak PP: Evaluation of therapeutic targets in animal models of arthritis: how does it relate to rheumatoid arthritis? Arthritis Rheum 2010, 62:2192-2205.

31. Fransen J, van Riel PL: The Disease Activity Score and the EULAR response criteria. Clin Exp Rheumatol 2005, 23:593-599.

doi:10.1186/ar3163

Cite this article as: Cardiel et al:: A phase 2 randomized, double-blind study of AMG 108, a fully human monoclonal antibody to IL-1R, in patients with rheumatoid arthritis. Arthritis Research \& Therapy 2010 12: R192.

\section{Submit your next manuscript to BioMed Central and take full advantage of:}

- Convenient online submission

- Thorough peer review

- No space constraints or color figure charges

- Immediate publication on acceptance

- Inclusion in PubMed, CAS, Scopus and Google Scholar

- Research which is freely available for redistribution 